\title{
Synthesis, Solution, and Structural Characterization of Tetrahydrofuranyl-2,2-Bisphosphonic Acid Disodium Salt
}

\author{
Elena Maltezou, ${ }^{1}$ Marios Stylianou, ${ }^{1}$ Sudeshna Roy, ${ }^{1}$ Chryssoula Drouza, ${ }^{2}$ \\ and Anastasios D. Keramidas ${ }^{1}$ \\ ${ }^{1}$ Department of Chemistry, University of Cyprus, 1678 Nicosia, Cyprus \\ ${ }^{2}$ Agricultural Production and Biotechnology and Food Science, Cyprus University of Technology, 3036 Lemesos, Cyprus
}

Correspondence should be addressed to Anastasios D. Keramidas, akeramid@ucy.ac.cy

Received 2 January 2010; Accepted 26 February 2010

Academic Editor: Spyros Perlepes

Copyright (c) 2010 Elena Maltezou et al. This is an open access article distributed under the Creative Commons Attribution License, which permits unrestricted use, distribution, and reproduction in any medium, provided the original work is properly cited.

\begin{abstract}
Bisphosphonates are biologically relevant therapeutics for bone disorders and cancer. Reaction of $\gamma$-chlorobutyric acid, phosphorus acid, and phosphorus trichloride without the use of solvent gave the tetrahydrofuranyl-2,2-bisphosphonate sodium salt $\left(\mathrm{Na}_{2} \mathrm{H}_{2} \mathrm{~L}\right)$. The $\mathrm{Na}_{2} \mathrm{H}_{2} \mathrm{~L}$ was isolated, characterized in solution by ${ }^{1} \mathrm{H},{ }^{13} \mathrm{C}$, and ${ }^{31} \mathrm{P} \mathrm{NMR}$ spectroscopy and in solid state by single X-Ray crystallography. The crystal structure showed that the $\mathrm{Na}_{2} \mathrm{H}_{2} \mathrm{~L}$ forms in the crystal infinite two-dimensional sheets stacked one parallel to the other. A comparison of the chelating properties of $\mathrm{H}_{2} \mathrm{~L}^{2-}$ with similar hydroxyl bisphosphonate ligands shows that the strength of the $\mathrm{Na}-\mathrm{O}$ (furanyl/hydroxyl) bond is directly related to the total charge of the ligand anion.
\end{abstract}

\section{Introduction}

Bisphosphonates (BPs) represent a very important class of compounds known for their medicinal and other properties $[1,2]$. In contrast to the naturally occurring pyrophosphate $\mathrm{P}-\mathrm{O}-\mathrm{P}$ group, these compounds contain a characteristic P$\mathrm{C}-\mathrm{P}$ bridge, which is chemically and enzymatically nonhydrolyzable. BPs exhibit specific affinity towards bone, which makes them an excellent therapeutic for bone resorption diseases (especially osteoporosis, Paget's disease, tumour induced osteolysis, hypercalcemia originated from malignancy) by inhibition of farnesyl diphosphate synthase (FPPS) and for bone tumour caused by metastatic breast tumours [3-5]. The biological activity of bisphosphonates has been found to be dependent on the structure [6], lipophilicity [7], and bone binding affinity [8] of the compounds. For example, the structure of the side chain of bisphosphonates is important in determining the potency of individual bisphosphonates in biological models, and this includes a potential role for the side chain in modulating bone binding. The presence and position of an oxygen or nitrogen atom within the side chain of bisphosphonates are directly related to their relative potency and bone binding affinity. In general, the oxygen/nitrogen containing bisphosphonates exhibits high bone binding affinities, which might be expected to reduce efficacy. However, some of these molecules are very potent and the difference in potency has been attributed to the inhibition of FPPS. Therefore, the structural characterization of bisphosphonates is very important tool for the elucidation of the mechanisms of the bone binding and biological activity and for the design of new, more potent compounds.

Herein, we report the synthesis, solution characterization, and crystal structure of the sodium salt of tetrahydrofuranyl-2,2-bisphosphonate $\left(\mathrm{Na}_{2} \mathrm{H}_{2} \mathrm{~L}\right)$. In the crystal the compound forms, the unusual for bisphosphonates, two-dimensional parallel sheets arrangement. A comparison of the chelating properties of $\mathrm{H}_{2} \mathrm{~L}^{2-}$ with similar hydroxyl bisphosphonate ligands shows that the $\mathrm{Na}-$ $\mathrm{O}$ (furanyl/hydroxyl) bond length increases as the charge of the ligand decreases. Thus, the weak $\mathrm{Na}-\mathrm{O}$ (furanyl) interaction is attributed to the -2 charge of the ligand.

\section{Materials and Methods}

2.1. Materials. The chemicals obtained from commercial sources were reagents grade and used as received. Solvents 
were freshly distilled and water was doubly distilled. $\gamma$ Chlorobutyric acid, phosphorus acid, and $\mathrm{D}_{2} \mathrm{O}$ were purchased from Sigma-Aldrich. Sodium hydroxide and phosphorus trichloride were purchased from Merck. Ethyl alcohol and methyl alcohol were bought from BDH. The synthesis was performed in inert Argon atmosphere.

2.2. Synthesis and Crystallization of Tetrahydrofuranyl-2,2Bisphosphonic Acid Disodium Salt $\left(\mathrm{Na}_{2} \mathrm{H}_{2} \mathrm{~L}\right)$. A mixture of $\gamma$-chlorobutyric acid $(7.12 \mathrm{~g}, 58.1 \mathrm{mmol})$, phosphorus acid (3.38 g, $41.2 \mathrm{mmol})$, and phosphorus trichloride (10.9 g, $79.4 \mathrm{mmol}$ ) was heated slowly to reach the temperature $80^{\circ} \mathrm{C}$ over an hour under constant flow of argon. The two-phase mixture was refluxed for 4 hours at $80^{\circ} \mathrm{C}$ and the viscous yellow mass was stirred vigorously for 10 hours at $60^{\circ} \mathrm{C}$. Precooled water $(125 \mathrm{~mL})$ was added slowly to the mixture under stirring as evolution of gaseous $\mathrm{HCl}$ was observed. The water $(110 \mathrm{~mL})$ was constantly removed by distillation from the orange reaction mass. Another $150 \mathrm{~mL}$ of water was added to the mixture and allowed to cool down slowly to room temperature $\left(25^{\circ} \mathrm{C}\right)$. The $\mathrm{pH}$ of the reaction mixture was adjusted to 3 by careful addition of $4 \mathrm{M} \mathrm{NaOH}$ solution. Absolute ethyl alcohol $(150 \mathrm{~mL})$ was poured slowly to the resulting yellow solution in order to induce crystallisation. White solid was formed after 12 hours stirring at $25^{\circ} \mathrm{C}$ and collected by filtration. The yellow filtrate was again treated with ethyl alcohol $(100 \mathrm{~mL})$ to obtain another batch of white solid. Total three batches were collected and for the crude product the yield was calculated to be $9.75 \mathrm{~g}$, (65\% based on $\gamma$-chlorobutyric acid). Crystallisation was performed by layering concentrated aqueous solution $(\mathrm{pH}$ $=4.2$ ) of $\mathrm{Na}_{2} \mathrm{H}_{2} \mathrm{~L}$ with methyl alcohol. Samples for NMR measurements were prepared by dissolution of the crystals in $\mathrm{D}_{2} \mathrm{O}$. The atoms have been numbered according to the numbering in Scheme 1. ${ }^{1} \mathrm{H}$ NMR $\delta\left(\mathrm{D}_{2} \mathrm{O}, \mathrm{ppm}\right): 3.90(\mathrm{t}$, ${ }^{2} J_{\mathrm{H}, \mathrm{H}}=6.7 \mathrm{~Hz}$, two protons $\left.\mathrm{H}(4)\right) ; 2.30\left(\mathrm{~m},{ }^{2} J_{\mathrm{H}, \mathrm{H}}=6.7 \mathrm{~Hz}\right.$, ${ }^{3} J_{\mathrm{H}, \mathrm{P}}=16.0 \mathrm{~Hz}$, two protons, $\left.\mathrm{H}(2)\right) ; 1.99\left(\mathrm{p},{ }^{2} J_{\mathrm{H}, \mathrm{H}}=6.7 \mathrm{~Hz}\right.$, two protons $\mathrm{H}(3)) .{ }^{13} \mathrm{C} \mathrm{NMR} \delta\left(\mathrm{D}_{2} \mathrm{O}, \mathrm{ppm}\right): 81.3\left(\mathrm{t},{ }^{1} J_{\mathrm{C}, \mathrm{P}}=\right.$ $144 \mathrm{~Hz}), \mathrm{C}(1) ; 70.3, \mathrm{C}(4) ; 30.2, \mathrm{C}(3) ; 26.8\left(\mathrm{t},{ }^{2} J_{\mathrm{C}, \mathrm{P}}=2.26 \mathrm{~Hz}\right)$, $\mathrm{C}(2) .{ }^{31} \mathrm{P} N M R \delta\left(\mathrm{D}_{2} \mathrm{O}, \mathrm{ppm}\right): 21.9\left(\mathrm{t},{ }^{3} \mathrm{~J}_{\mathrm{H}, \mathrm{P}}=16.0 \mathrm{~Hz}\right)$. Anal. Calcd. for $\mathrm{C}_{4} \mathrm{H}_{8} \mathrm{Na}_{2} \mathrm{O}_{7} \mathrm{P}_{2}$ (f.w.: 276.02): C, 17.41; H, 2.92 . Found: C, 17.38; H, 2.89.

2.3. NMR Studies. The one-dimensional ${ }^{1} \mathrm{H},{ }^{13} \mathrm{C}$, and ${ }^{31} \mathrm{P}$ spectra were recorded in a $300 \mathrm{MHz}$ Avance Bruker spectrophotometer at $300.13 \mathrm{MHz}$ for ${ }^{1} \mathrm{H}, 121.46 \mathrm{MHz}$ for ${ }^{31} \mathrm{P}$, and $75.47 \mathrm{MHz}$ for ${ }^{13} \mathrm{C}$ with a $5 \mathrm{~mm}$ multinucleus probe at ambient temperature $\left(25^{\circ} \mathrm{C}\right)$ in $\mathrm{D}_{2} \mathrm{O}$ solution. A $30^{\circ}$-pulse width and 1-second relaxation delay were applied for ${ }^{1} \mathrm{H}$, ${ }^{31} \mathrm{P}$, and ${ }^{13} \mathrm{C}$ NMR spectra.

2.4. X-Ray Crystallography. Crystal data, details of data collection, and refinement of crystal structure of $\mathrm{Na}_{2} \mathrm{H}_{2} \mathrm{~L}$ are provided in Table 1. The intensity data for the compound were collected at $100 \mathrm{~K}$ on an XCalibur III 4-cycle diffractometer, equipped with a CCD camera detector. The experimental data were collected using Mo $\operatorname{K} \alpha$ radiation $(\lambda=0.7107 \AA)$ at a crystal-to-detector distance $60 \mathrm{~mm}$. The structure was solved

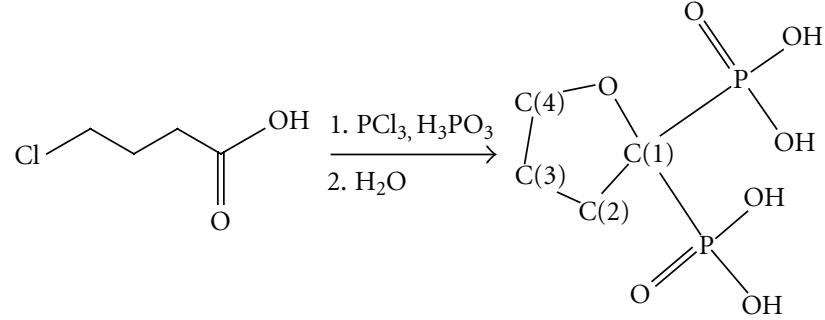

Scheme 1: Synthetic methodology for synthesis of $\mathrm{Na}_{2} \mathrm{H}_{2} \mathrm{~L}$ along with the numbering scheme of $\mathrm{C}$-atoms for NMR peak assignments.

TABle 1: Crystallographic and experimental data for compound $\mathrm{Na}_{2} \mathrm{H}_{2} \mathrm{~L}^{\mathrm{a}}$, b

\begin{tabular}{|c|c|}
\hline Empirical formula & $\mathrm{C}_{4} \mathrm{H}_{6} \mathrm{Na}_{2} \mathrm{O}_{7} \mathrm{P}_{2}$ \\
\hline Formula mass & 274.01 \\
\hline Crystal system & Triclinic \\
\hline Space group & $P-1$ \\
\hline$a / \AA$ & $6.327(5)$ \\
\hline$b / \AA$ & $6.967(5)$ \\
\hline$c / \AA$ & $11.805(5)$ \\
\hline$\alpha /^{\circ}$ & $93.067(5)$ \\
\hline$\beta /^{\circ}$ & $96.222(5)$ \\
\hline$\gamma /{ }^{\circ}$ & $113.594(5)$ \\
\hline$V / \AA^{3}$ & $471.4(5)$ \\
\hline$Z$ & 2 \\
\hline$D_{\mathrm{c}} / \mathrm{g} \mathrm{cm}^{-3}$ & 1.930 \\
\hline Absorption coefficient $/ \mathrm{cm}^{-1}$ & 0.564 \\
\hline$F(000)$ & 276 \\
\hline \multirow[t]{2}{*}{$\theta$ range for data collection $/^{\circ}$} & $3.7788-62.3061$ \\
\hline & $-7 \leq h \leq 7$ \\
\hline \multirow[t]{2}{*}{ Ranges for $h, k, l$} & $-8 \leq h \leq 7$ \\
\hline & $-11 \leq h \leq 13$ \\
\hline Reflections collected/unique & $2384 / 1451$ \\
\hline$R_{\text {int }}$ & 0.0218 \\
\hline Data/restraints/parameters & $3667 / 0 / 171$ \\
\hline GOF on $F^{2}$ & 1.158 \\
\hline$a, b$ in weighting scheme & $0.1390 / 0.0668$ \\
\hline Final $R / R_{\mathrm{w}}$ indices $(I>2 \sigma(I))$ & $0.0572 / 0.2162$ \\
\hline Final $R / R_{\mathrm{w}}$ indices (all data) & $0.0827 / 0.2288$ \\
\hline
\end{tabular}

a All structures determined at $T=100 \mathrm{~K}$ using Mo $K \alpha$ radiation $(\lambda=$ $0.71073 \AA)$.

${ }^{\mathrm{b}} R=\Sigma\left\|F_{\mathrm{o}}|-| F_{\mathrm{c}}\right\| / \Sigma\left|F_{o}\right|, w R=\left[\Sigma w\left(\left|F_{o}\right|^{2}-\left|F_{c}\right|^{2}\right) / \Sigma w\left|F_{o}\right|^{2}\right]^{1 / 2}, \mathrm{GOF}=$ $\left[\Sigma\left[w\left(F_{o}^{2}-F_{c}^{2}\right)^{2}\right] /(n-p)\right]^{1 / 2}, w=1 /\left[\sigma^{2}\left(F_{o}^{2}\right)+(a P)^{2}+b P\right]$, where $P=$ $\left(F_{o}^{2}+2 F_{c}^{2}\right) / 3$.

by direct methods using the programs SHELXS-86 and refined anisotropically (nonhydrogen atoms) by full-matrix least squares on $F^{2}[9,10]$. The $\mathrm{H}$ atoms were calculated geometrically and refined with riding model with isotropic displacement parameters. The programs ORTEP-3 [11] and Diamond-3 were used for diagrams and WINGX [12] was used to prepare material for publication. 


\section{Results and Discussion}

3.1. Synthesis. Compound $\mathrm{Na}_{2} \mathrm{H}_{2} \mathrm{~L}$ has been synthesized by heating at $80^{\circ} \mathrm{C}$ the mixture of $\gamma$-chlorobutyric acid, phosphorus acid, and phosphorus trichloride (Scheme 1). This molecule has been previously synthesized by Kieczykowski et al. [13] following a similar procedure by heating the mixture at $65^{\circ} \mathrm{C}$ in methanesulfonic acid. However, the product isolated from that reaction had always been contaminated with the methanesulfonate salt and the yield of the reaction was less than $30 \%$. In contrast, the reaction without the use of solvent gave pure product and yield more than $60 \%$. Upon completion of the reaction, it is quenched with water. The product was crystallized by addition of ethanol in an aqueous solution of $\mathrm{Na}_{2} \mathrm{H}_{2} \mathrm{~L}$ at $\mathrm{pH}$ 3.0. It is worth to notice that the isolated compound is the disodium salt of the bisphosphonate anion although it has been isolated at $\mathrm{pH}$ lower than that of the monosodium salt ( $\mathrm{pH} 4.3$ ) by Kieczykowski et al. This difference is attributed to the different methodology used for the crystallization of the product.

3.2. Solution Characterization. The molecule was characterized in aqueous solution by ${ }^{1} \mathrm{H},{ }^{13} \mathrm{C}$, and ${ }^{31} \mathrm{P}$ NMR spectroscopy. The $J$ coupling constants were used to confirm the assignments made by the NMR spectra. The ${ }^{31} \mathrm{P}$ NMR spectrum gave one triplet due to the coupling $\left({ }^{3} J_{\mathrm{HP}}=\right.$ $16.0 \mathrm{~Hz}$ ) of phosphorus nuclei with the two $\mathrm{H}(2)$ protons at $21.9 \mathrm{ppm}$. This chemical shift is close to the chemical shifts of other hydroxyl bisphosphonates such as etidronate (L1, Scheme 2) (22.9 ppm) [14]. The ${ }^{13} \mathrm{C}$ spectrum of $\mathrm{Na}_{2} \mathrm{H}_{2} \mathrm{~L}$ showed a triplet assigned to $\mathrm{C}(1)$. The splitting of this peak is assigned to the strong coupling of $\mathrm{C}(1)$ with the two phosphorus atoms $\left({ }^{1} J_{\mathrm{CP}}=144.0 \mathrm{~Hz}\right)$. The weak coupling of $\mathrm{C}(2)$ with the two phosphorus nuclei $\left({ }^{2} J_{\mathrm{C}, \mathrm{P}}=2.26 \mathrm{~Hz}\right)$ gives a triplet feature for this peak that can be easily distinguished from the peak assigned to $\mathrm{C}(3)$. The ${ }^{1} \mathrm{H}$ NMR spectrum exhibits a triplet for $\mathrm{H}(4)$ protons (due to the coupling with the two $\mathrm{H}(3)$ protons), a quintuplet for $\mathrm{H}(3)$ (due to the coupling with the two $\mathrm{H}(2)$ and two $\mathrm{H}(4)$ protons), and a multiplet for $\mathrm{H}(2)$ (due to the coupling with the two $\mathrm{H}(3$ ) protons and the two $\mathrm{P}$ atoms).

3.3. X-Ray Crystallographic Structure. The molecular structure of $\mathrm{Na}_{2} \mathrm{H}_{2} \mathrm{~L}$ is shown in Figures 1 and 2(a). Crystallographic data are provided in Table 1. Tables 3 and 4 contain the interatomic bond lengths and angles of $\mathrm{Na}_{2} \mathrm{H}_{2} \mathrm{~L}$. The bisphosphonate anion in the structure of $\mathrm{Na}_{2} \mathrm{H}_{2} \mathrm{~L}$ possesses an overall -2 charge, thus two of the phosphonate oxygen atoms are deprotonated $\left(\mathrm{P}^{-} \mathrm{O}^{-}\right)$, two have protons attached $(\mathrm{P}-\mathrm{OH})$, and two form double bond with phosphorous $(\mathrm{P}=\mathrm{O})$. Both phosphorous atoms exhibit distorted tetrahedral geometries. The $\mathrm{P}-\mathrm{O}$ bond lengths are close to $1.50 \AA$ for the $\mathrm{P}-\mathrm{O}$ (deprotonated) and $1.57 \AA$ for the $\mathrm{P}-\mathrm{OH}$ (protonated). Although the $\mathrm{P}-\mathrm{OH}$ bonds can be located very easily by inspection of the bond distances, the $\mathrm{P}-$ $\mathrm{O}^{-}$and $\mathrm{P}=\mathrm{O}$ cannot be distinguished because of the charge delocalization over the ${ }^{-} \mathrm{O}-\mathrm{P}=\mathrm{O}$ groups. The bond angles around $\mathrm{P}(1), \mathrm{P}(2)$ range from $104.0(4)$ to $116.4(3)^{\circ}$. The $\mathrm{O}-$ $\mathrm{P}-\mathrm{O}$ angles involving the two unprotonated oxygen atoms

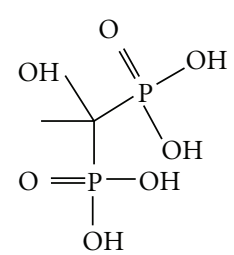

Etidronate, L1

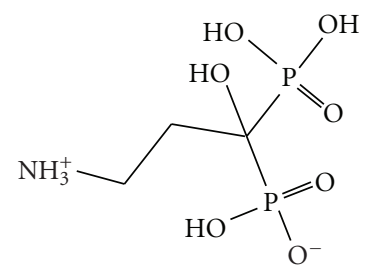

Pamidronate, L2

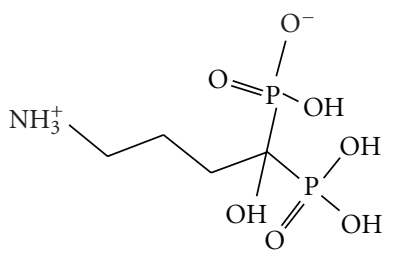

Alendronate, L3

Scheme 2: Molecular structures of etidronate, pamidronate, and alendronate and abbreviations used in the document.

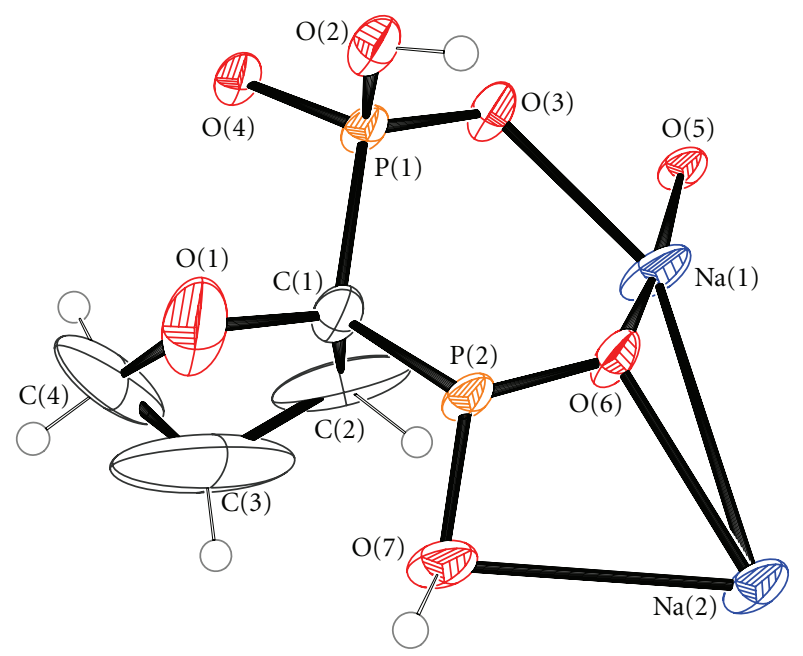

FIGURE 1: ORTEP representation of the main structural motif observed in $\mathrm{Na}_{2} \mathrm{H}_{2} \mathrm{~L}$. Ellipsoids are drawn at the $50 \%$ probability level.

are the largest ones in both phosphonate groups. The two phosphorus centers are fairly close (3.087(3) $\AA$ ), due to their bisectional positions relative to $\mathrm{C}(1)$ on the furanyl ring $\left(\mathrm{P}(1)-\mathrm{C}(1)-\mathrm{P}(2)=114.7(5)^{\circ}\right)$. The $\mathrm{P} \cdots \mathrm{P}$ distance is a little larger than the distance (3.035(3) $\AA$ ) observed in the crystal structure of nitrogen containing respective molecule, the pyrrolidine-2,2-diylbisphosphonic acid [15].

The coordination sphere is different for each of the two sodium atoms (Figures 3(a) and 3(b)). The $\mathrm{Na}(1)$ exhibits a distorted octahedral environment defined by $\mathrm{O}(5), \mathrm{O}(4)$, $\mathrm{O}(2), \mathrm{O}(6), \mathrm{O}(3)$, and $\mathrm{O}\left(3^{\prime}\right)$. The $\mathrm{Na}(2)$ exhibits a capped octahedral geometry with the $\mathrm{O}(1), \mathrm{O}(2), \mathrm{O}(3), \mathrm{O}(5), \mathrm{O}(6)$, and $\mathrm{O}\left(6^{\prime}\right)$ to define an octahedron and the $\mathrm{O}(7)$ added to the triangular face defined by $\mathrm{O}(1), \mathrm{O}(3)$, and $\mathrm{O}(6)$. The $\mathrm{Na}-\mathrm{O}$ bond distances range between 2.327(7) and 2.872(7) $\AA$ with the $\mathrm{Na}(2)-\mathrm{O}(7)$ to exhibit the longest bond distance. The sodium-centered octahedrons and capped octahedrons form 
TABLE 2: Selected bond lengths $(\AA)$ for $\mathrm{Na}_{2} \mathrm{H}_{2} \mathrm{~L}$.

\begin{tabular}{lllr}
\hline $\mathrm{C}(1)-\mathrm{O}(1)$ & $1.48(2)$ & $\mathrm{P}(1)-\mathrm{O}(2)$ & $1.571(8)$ \\
$\mathrm{C}(1)-\mathrm{C}(2)$ & $1.50(2)$ & $\mathrm{P}(1)-\mathrm{O}(3)$ & $1.499(7)$ \\
$\mathrm{C}(2)-\mathrm{C}(3)$ & $1.59(3)$ & $\mathrm{P}(1)-\mathrm{O}(4)$ & \\
$\mathrm{C}(3)-\mathrm{C}(4)$ & $1.50(4)$ & $\mathrm{P}(2)-\mathrm{O}(5)$ & $1.499(5)$ \\
$\mathrm{C}(4)-\mathrm{O}(1)$ & $1.42(2)$ & $\mathrm{P}(2)-\mathrm{O}(6)$ & $\mathrm{P}(2)-\mathrm{O}(7)$ \\
$\mathrm{C}(1)-\mathrm{P}(1)$ & $1.834(9)$ & $\mathrm{Na}(2)-\mathrm{O}(1)$ & $1.507(7)$ \\
$\mathrm{C}(1)-\mathrm{P}(2)$ & $1.833(7)$ & $\mathrm{Na}(2)-\mathrm{O}(2)$ & $1.493(7)$ \\
$\mathrm{Na}(1)-\mathrm{O}(2)$ & $2.625(7)$ & $\mathrm{Na}(2)-\mathrm{O}(3)$ & $2.79(2)$ \\
$\mathrm{Na}(1)-\mathrm{O}(3)$ & $2.335(7)$ & $\mathrm{Na}(2)-\mathrm{O}(5)$ & $2.494(8)$ \\
$\mathrm{Na}(1)-\mathrm{O}\left(3^{\prime}\right)$ & $2.671(8)$ & $\mathrm{Na}(2)-\mathrm{O}(6)$ & $2.371(7)$ \\
$\mathrm{Na}(1)-\mathrm{O}(4)$ & $2.449(8)$ & $\mathrm{Na}(2)-\mathrm{O}\left(6^{\prime}\right)$ & $2.405(7)$ \\
$\mathrm{Na}(1)-\mathrm{O}(5)$ & $2.480(7)$ & $2.423(8)$ \\
$\mathrm{Na}(1)-\mathrm{O}(6)$ & $2.327(7)$ & $2.458(6)$ \\
\hline
\end{tabular}

astandard deviations are given in parentheses.

'Symmetry operations: $x, y, z ;-x,-y,-z$.

TABLE 3: Selected bond angles $\left({ }^{\circ}\right)$ for $\mathrm{Na}_{2} \mathrm{H}_{2} \mathrm{~L}$.

\begin{tabular}{lclr}
\hline $\mathrm{O}(2)-\mathrm{P}(1)-\mathrm{O}(3)$ & $110.7(3)$ & $\mathrm{O}(5)-\mathrm{P}(2)-\mathrm{O}(6)$ & $115.1(3)$ \\
$\mathrm{O}(2)-\mathrm{P}(1)-\mathrm{O}(4)$ & $105.5(3)$ & $\mathrm{O}(5)-\mathrm{P}(2)-\mathrm{O}(7)$ & $110.1(4)$ \\
$\mathrm{O}(3)-\mathrm{P}(1)-\mathrm{O}(4)$ & $116.4(4)$ & $\mathrm{O}(6)-\mathrm{P}(2)-\mathrm{O}(7)$ & $109.3(4)$ \\
$\mathrm{C}(1)-\mathrm{P}(1)-\mathrm{O}(2)$ & $105.2(4)$ & $\mathrm{C}(1)-\mathrm{P}(2)-\mathrm{O}(5)$ & $108.6(4)$ \\
$\mathrm{C}(1)-\mathrm{P}(1)-\mathrm{O}(3)$ & $110.9(4)$ & $\mathrm{C}(1)-\mathrm{P}(2)-\mathrm{O}(6)$ & $109.2(4)$ \\
$\mathrm{C}(1)-\mathrm{P}(1)-\mathrm{O}(4)$ & $107.4(4)$ & $\mathrm{C}(1)-\mathrm{P}(2)-\mathrm{O}(7)$ & $104.0(4)$ \\
$\mathrm{O}(1)-\mathrm{C}(1)-\mathrm{P}(1)$ & $106.5(6)$ & $\mathrm{O}(1)-\mathrm{C}(1)-\mathrm{P}(2)$ & $105.2(6)$ \\
$\mathrm{C}(2)-\mathrm{C}(1)-\mathrm{P}(1)$ & $107.9(8)$ & $\mathrm{C}(2)-\mathrm{C}(1)-\mathrm{P}(2)$ & $110.7(8)$ \\
$\mathrm{O}(1)-\mathrm{C}(1)-\mathrm{C}(2)$ & $112.0(9)$ & $\mathrm{P}(1)-\mathrm{C}(1)-\mathrm{P}(2)$ & $114.6(5)$ \\
$\mathrm{C}(1)-\mathrm{O}(1)-\mathrm{C}(4)$ & $105(1)$ & $\mathrm{C}(1)-\mathrm{C}(2)-\mathrm{C}(3)$ & $100(1)$ \\
$\mathrm{O}(1)-\mathrm{C}(4)-\mathrm{C}(3)$ & $107(2)$ & $\mathrm{C}(2)-\mathrm{C}(3)-\mathrm{C}(4)$ & $103(2)$ \\
\hline
\end{tabular}

${ }^{\text {a }}$ Standard deviations are given in parentheses.

bymmetry operations: $x, y, z ;-x,-y,-z$.

TABLE 4: Selected bond lengths for $\mathrm{Na}^{+}$and $\mathrm{Ca}^{2+}$ bisphosphonate complexes. The L, L1, L2, L3 bisphosphonates are according to Scheme 2 .

\begin{tabular}{|c|c|c|c|c|c|}
\hline Compound & $\begin{array}{c}\text { Charge of } \\
\text { bisphosphonate anion }\end{array}$ & $\mathrm{M}-\mathrm{O}_{\text {hydroxy/furanyl }} / \AA$ & $\begin{array}{c}\text { Shortest } \\
\mathrm{M}-\mathrm{O}_{\text {phosporyl }} / \AA\end{array}$ & $\begin{array}{c}\text { Longest } \\
\mathrm{M}-\mathrm{O}_{\text {phosporyl }} / \AA\end{array}$ & References \\
\hline $\mathrm{Na}_{2} \mathrm{H}_{2} \mathrm{~L}$ & $(-2)$ & $2.79(1)$ & $2.327(7)$ & $2.873(8)$ & This work \\
\hline $\mathrm{CaH}_{2} \mathrm{~L} 1$ & $(-2)$ & $2.608(2)$ & $2.352(1)$ & $2.608(2)$ & {$[16]$} \\
\hline $\mathrm{NaH}_{3} \mathrm{~L} 1$ & $(-1)$ & $2.470(4)$ & $2.230(4)$ & $2.447(4)$ & [17] \\
\hline $\mathrm{NaH}_{3} \mathrm{~L} 1$ & $(-1)$ & $2.463(2)$ & $2.293(3)$ & $2.444(2)$ & {$[18]$} \\
\hline $\mathrm{CaH}_{2} \mathrm{~L} 2$ & $(-2)$ & a & $2.288(1)$ & $2.387(1)$ & [19] \\
\hline $\mathrm{Na}_{2} \mathrm{H}_{2} \mathrm{~L} 2$ & $(-2)$ & $2.828(3)$ & $2.274(3)$ & $2.691(3)$ & {$[20]$} \\
\hline $\mathrm{NaH}_{3} \mathrm{~L} 2$ & $(-1)$ & $2.537(2)$ & $2.261(2)$ & $2.438(2)$ & {$[21]$} \\
\hline $\mathrm{CaH}_{2} \mathrm{~L} 3$ & $(-2)$ & a & $2.304(1)$ & $2.345(1)$ & {$[22]$} \\
\hline
\end{tabular}

a Non bonding distance above $3 \AA$.

an edge-sharing linear array directed along the axis $(1,1,0)$ of the crystal (Figure 3(a)). These arrays are connected to each other with the diphosphonate anions (Figure 3(b)) forming infinite $2 \mathrm{D}$ sheets. The two-dimensional networks are stacked one over the other along axis $c$ (Figure $3(\mathrm{c})$ ).
The distance between the mean planes defined from the atoms of two successive sheets is $11.668(5) \AA$. This distance is actually the length of the $c$ axis. The furanyl rings are located above and below the $2 \mathrm{D}$ structures insulating the sodium ions in each layer. It is possible that this unusual for 


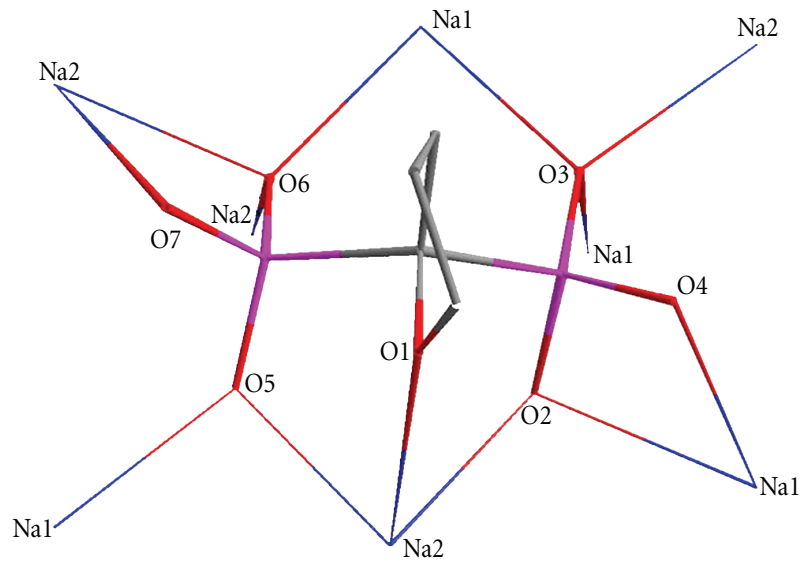

(a)

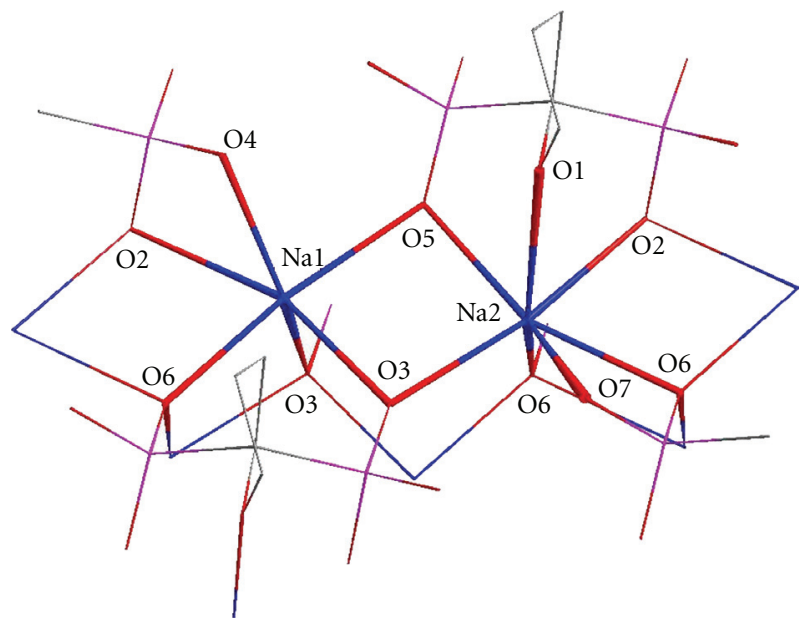

(b)

FIGURE 2: (a) Stick representation of $\mathrm{H}_{2} \mathrm{~L}^{2-}$ showing the connectivity with sodium ions. (b) Stick representation of $\mathrm{Na}_{2} \mathrm{H}_{2} \mathrm{~L}$ showing the coordination environment of sodium ions.

diphosphonates two-dimensional structure is induced by the hydrophobic furanyl rings which prevent any electrostatic interlayer interactions.

A recent study [23] has shown that bisphosphonates binding strength can be calculated by summarizing the interactions of the phosphonate groups, the side chain groups, the hydroxyl group, and the hydrophobic group of the ligand with the bone surface. Most importantly, it has been found that although the $-\mathrm{OH}$ group is necessary for the strong binding of phosphonates on the bone, the interaction of the $-\mathrm{OH}$ with the bone surface is weak. Selected bond lengths of $\mathrm{Na}^{+}-\mathrm{O} / \mathrm{Ca}^{2+}-\mathrm{O}$ of similar tetrahydrofuranyl-2,2bisphosphonate compounds extracted from their crystal structure are shown in Table 4. The comparison shows that the chelating properties of the ligands are in good agreement with their binding properties on bone surface. Thus, the bond distances between the donor oxygen atoms of bisphosphonate ligand and the cations might give an estimation of the bisphosphonates bone binding strength. The $\left(\mathrm{Na}^{+} / \mathrm{Ca}^{2+}\right)-\mathrm{O}$ (phosphoryl) bond distances are similar,

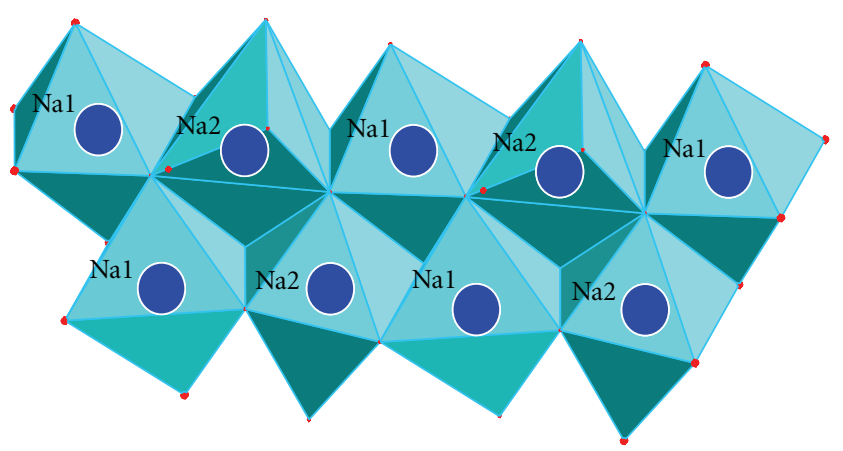

(a)

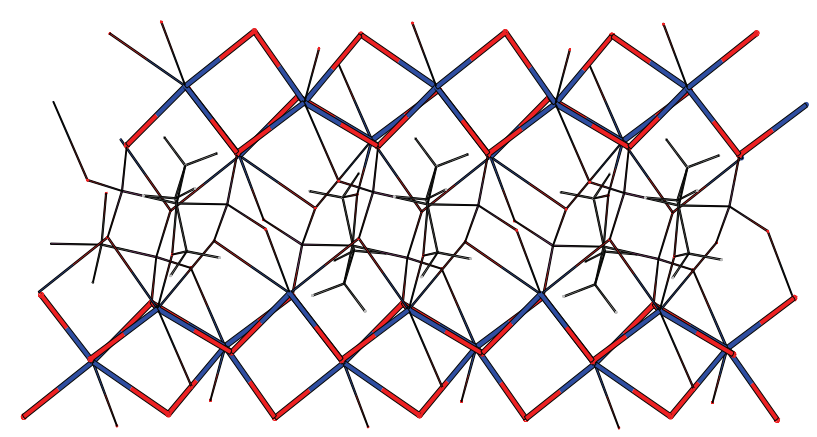

(b)

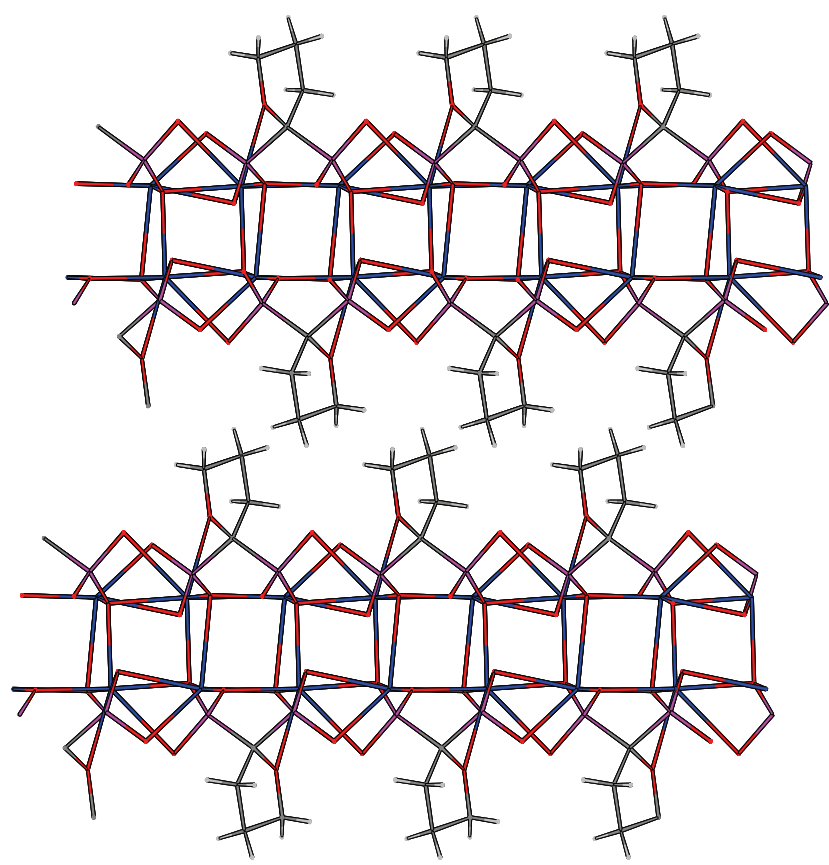

(c)

FIGURE 3: (a) Sodium-centered polyhedral connected to each other to form linear arrays along axis $(1,1,0)$. (b) Connection of the linear sodium arrays with bisphosphonate anions to form two dimensional sheets. (c) Two layers stacked one parallel to the other along axis $c$. 
within the range 2.261 to $2.873 \AA$, suggesting that the interaction of all phosphonate groups with the bone is of similar strength for all ligands. In all crystal structures of the calcium salts of the bisphoshonates, except the structure of etidronate, the metal ion is ligated only to the phosphonate oxygen atoms. The charge of the ligand in all calcium structures is -2 . In contrast, the $\mathrm{Na}^{+}$ions have been found to be ligated both to the phosphonate and the hydroxyl oxygen in the structures of the sodium salts of the respective ligands. However, the $\mathrm{Na}^{+}-\mathrm{O}$ bond length is much shorter in the structures of monoanion bisphosphonate structures $(\sim 2.5 \AA)$ than in the respective dianions $(\sim 2.8 \AA)$ including $\mathrm{Na}_{2} \mathrm{H}_{2} \mathrm{~L}$. Apparently, this bond length comparison indicates that the $\mathrm{Na}^{+}-\mathrm{O}$ (hydroxyl/furanyl) bond strength is directly dependent on the total charge of the bisphosphonate ligand; the bond length increases by decreasing the charge of the ligand. In addition, the weak interaction of hydroxyl group with the bone [23] also suggests that the total charge of the ligand that binds the bone surface is -2 .

The $\mathrm{Na}^{+}-\mathrm{O}$ bond distances found in the crystal structure of $\mathrm{Na}_{2} \mathrm{H}_{2} \mathrm{~L}$ are close to the respective bond distance of $\mathrm{Na}_{2} \mathrm{H}_{2} \mathrm{~L} 2$ (L2 = pamidronate, Scheme 2) showing that the contribution of these bonds for bone binding is similar [20]. However, the tetrahydrofuranyl side chain does not contain any group that will contribute to the bone binding, thus it is expected that $\mathrm{H}_{2} \mathrm{~L}^{2-}$ will be a weaker bone binder than $\mathrm{H}_{2} \mathrm{L1}^{2-}, \mathrm{H}_{2} \mathrm{~L}^{2-}$, and $\mathrm{H}_{2} \mathrm{~L}^{2-}$ (Scheme 2).

\section{Conclusions}

The tetrahydrofuranyl-2,2-bisphosphonic acid has been prepared with an efficient method without the use of solvent, producing pure product in high yield over $60 \%$. The crystal structure of the complex showed that the disodium salt of bisphosphonate crystallizes forming two-dimensional sheets stacked parallel one over the other.

The results of this study show that the crystallographic characterization of a widely used class of drug molecules, the bisphosphonate salts, provide important information on their biological activity (bone binding, FPPS inhibition), and can be used for the design of new more active molecules. The bisphosphonates binding strength with bone can be calculated by summarizing the interactions of the phosphonate groups, the side chain groups, the hydroxyl group, and the hydrophobic group of the ligand with the bone surface. The crystallographic data of the $\mathrm{Na}^{+} / \mathrm{Ca}^{2+}$ salts of bisphosphonate show that the interaction of the $-\mathrm{OH}$ group with the metal ions is weak which is in agreement with the results from a recent study [23] on the interaction of the bisphosphonates with bone surface. Furthermore a comparison of $\mathrm{Na}^{+} / \mathrm{Ca}^{2+}$ bisphosphonate structures shows that the strength of the $\mathrm{Na}-\mathrm{O}$ (hydroxyl/furanyl) bond reduces with the decrease of the total bisphosphonate anion charge.

\section{Acknowledgment}

The authors thank the Research Promotion Foundation of Cyprus for the financial support of this work with the proposal YГЕIA/BIO $\Sigma / 0308(\mathrm{BIE}) / 03$.

\section{References}

[1] W. M. Abdou and A. A. Shaddy, "The development of bisphosphonates for therapeutic uses, and bisphosphonate structureactivity consideration," Arkivoc, vol. 2009, no. 9, pp. 143-182, 2009.

[2] H. Fleisch, "Bisphosphonates: mechanisms of action," Endocrine Reviews, vol. 19, no. 1, pp. 80-100, 1998.

[3] J. J. Body, R. Bartl, P. Burckhardt, et al., "Current use of bisphosphonates in oncology," Journal of Clinical Oncology, vol. 16, no. 12, pp. 3890-3899, 1998.

[4] R. G. G. Russell and M. J. Rogers, "Bisphosphonates: from the laboratory to the clinic and back again," Bone, vol. 25, no. 1, pp. 97-106, 1999.

[5] H. Fleisch, "Bisphosphonates in osteoporosis," European Spine Journal, vol. 12, supplement 2, pp. S142-S146, 2003.

[6] R. G. G. Russell, "Determinants of structure-function relationships among bisphosphonates," Bone, vol. 40, no. 5, supplement 2, pp. S21-S25, 2007.

[7] Y. Zhang, R. Cao, F. Yin, et al., "Lipophilic bisphosphonates as dual farnesyl/geranylgeranyl diphosphate synthase inhibitors: an X-ray and NMR investigation," Journal of the American Chemical Society, vol. 131, no. 14, pp. 5153-5162, 2009.

[8] G. H. Nancollas, R. Tang, R. J. Phipps, et al., "Novel insights into actions of bisphosphonates on bone: differences in interactions with hydroxyapatite," Bone, vol. 38, no. 5, pp. 617-627, 2006.

[9] G. M. Sheldrick, "SHELX-86: program for the solution of crystal structures," 1990.

[10] G. M. Sheldrick, "SHELXL-97, program for crystal structure refinement," 1997.

[11] L. J. Farrugia, "ORTEP-3 for windows-a version of ORTEPIII with a graphical user interface (GUI)," Journal of Applied Crystallography, vol. 30, no. 5, p. 565, 1997.

[12] L. J. Farrugia, "WinGX suite for small-molecule single-crystal crystallography," Journal of Applied Crystallography, vol. 32, no. 4, pp. 837-838, 1999.

[13] G. R. Kieczykowski, R. B. Jobson, D. G. Melillo, D. F. Reinhold, V. J. Grenda, and I. Shinkai, "Preparation of (4-amino1-hydroxybutylidene)bisphosphonic acid sodium salt, MK217 (alendronate sodium). An improved procedure for the preparation of 1-hydroxy-1,1-bisphosphonic acids," Journal of Organic Chemistry, vol. 60, no. 25, pp. 8310-8312, 1995.

[14] I. Cukrowski, L. Popoviç, W. Barnard, S. O. Paul, P. H. van Rooyen, and D. C. Liles, "Modeling and spectroscopic studies of bisphosphonate-bone interactions. The Raman, NMR and crystallographic investigations of Ca-HEDP complexes," Bone, vol. 41, no. 4, pp. 668-678, 2007.

[15] G. Olive, D. D. Ellis, D. Siri, et al., "Zwitterionic pyrrolidine2,2-diylbis(phosphonic acid) at 100, 150 and $293 \mathrm{~K}$," Acta Crystallographica, Section C, vol. 56, no. 6, pp. 720-722, 2000.

[16] V. A. Uchtman, "Structural investigations of calcium binding molecules. II. The crystal and molecular structures of calcium dihydrogen ethane-1-hydroxy-1,1-diphosphonate dihydrate, $\mathrm{CaC}\left(\mathrm{CH}_{3}\right)(\mathrm{OH})\left(\mathrm{PO}_{3} \mathrm{H}\right)_{2} \cdot 2 \mathrm{H}_{2} \mathrm{O}$; implications for polynuclear complex formation," The Journal of Physical Chemistry, vol. 76, no. 9, pp. 1304-1310, 1972.

[17] Z. Wu, Z. Liu, P. Tian, et al., "Two Cr" ${ }^{\mathrm{III}}$ containing metal1-hydroxyethylidenediphosphonate compounds: synthesis, structure, and morphology," Crystal Research and Technology, vol. 41, no. 10, pp. 1049-1054, 2006. 
[18] L. M. Shkol'nikova, A. A. Masyuk, and E. G. Afonin, "Structural chemistry of 1-hydroxyethylidenediphosphonic acid complexes," Koordinatsionnaya Khimiya, vol. 16, p. 902, 1990 (Russian).

[19] D. Fernández, D. Vega, and A. Goeta, "The calcium-binding properties of pamidronate, a bone-resorption inhibitor," Acta Crystallographica Section C, vol. 58, no. 10, pp. m494-m497, 2002.

[20] D. Vega, D. Fernández, and J. A. Ellena, "Disodium pamidronate," Acta Crystallographica Section C, vol. 58, no. 2, pp. m77-m80, 2002.

[21] K. Stahl, S. P. Treppendahl, H. Preikschat, and E. Fischer, "Sodium 3-ammonio-1-hydroxypropylidene-1,1-bisphosphonate- monohydrate," Acta Crystallographica Section E, vol. 61, no. 1, pp. m132-m134, 2005.

[22] D. Fernández, D. Vega, and A. Goeta, "Alendronate zwitterions bind to calcium cations arranged in columns," Acta Crystallographica Section C, vol. 59, no. 12, pp. m543-m545, 2003.

[23] S. Mukherjee, C. Huang, F. Guerra, K. Wang, and E. Oldfield, "Thermodynamics of bisphosphonates binding to human bone: a two-site model," Journal of the American Chemical Society, vol. 131, no. 24, pp. 8374-8375, 2009. 


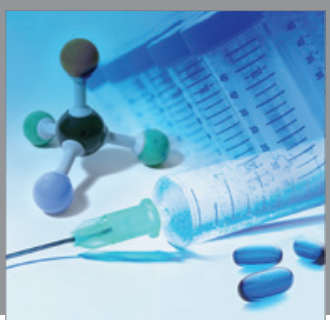

International Journal of

Medicinal Chemistry

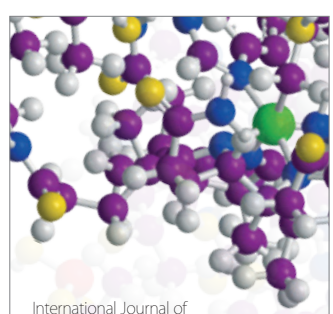

Carbohydrate Chemistry

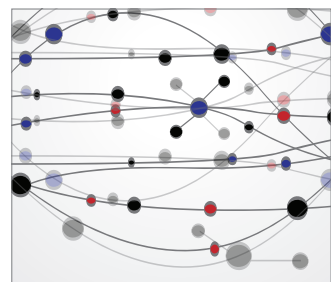

The Scientific World Journal
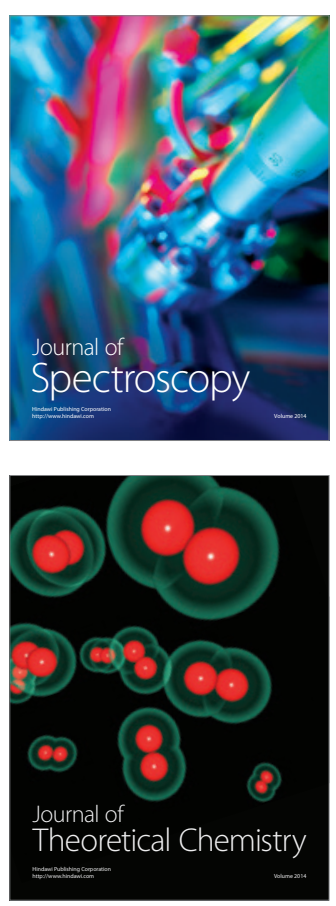
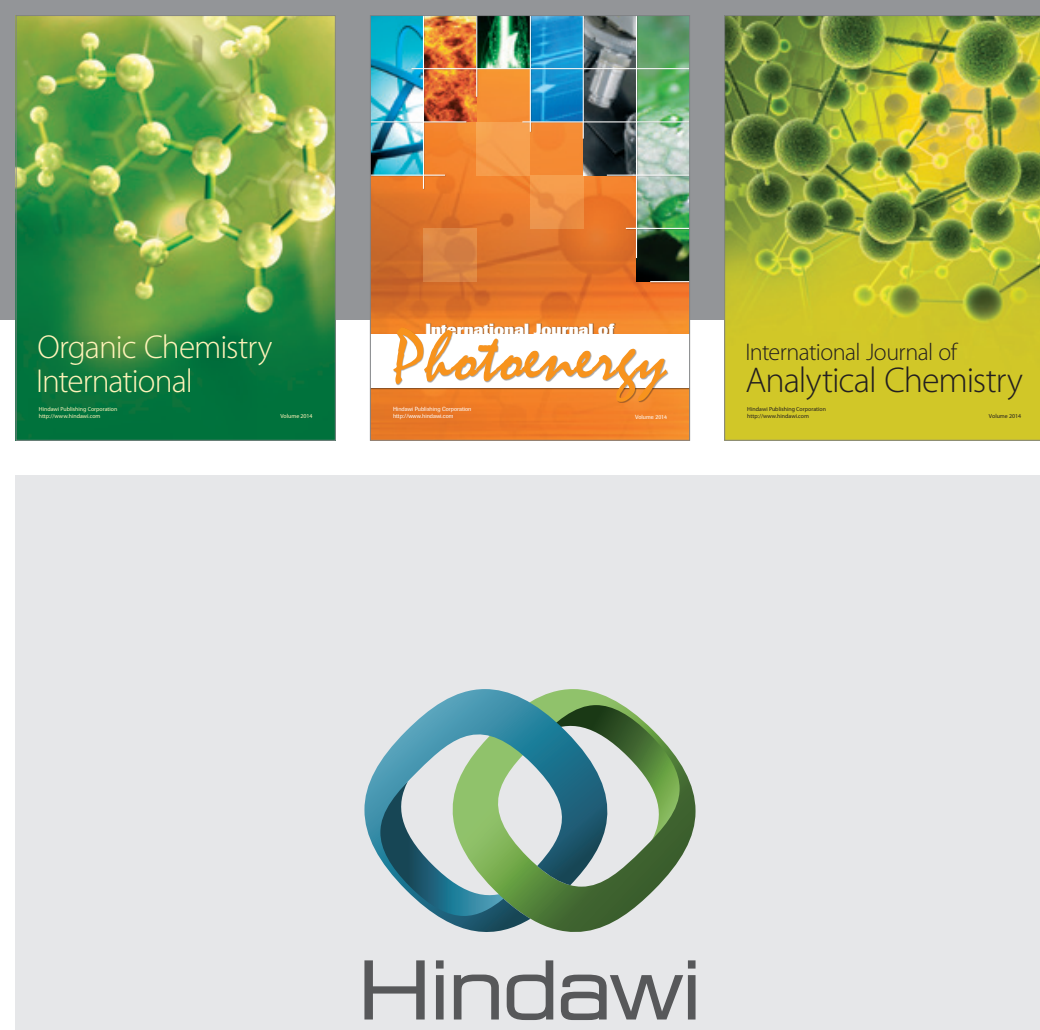

Submit your manuscripts at

http://www.hindawi.com
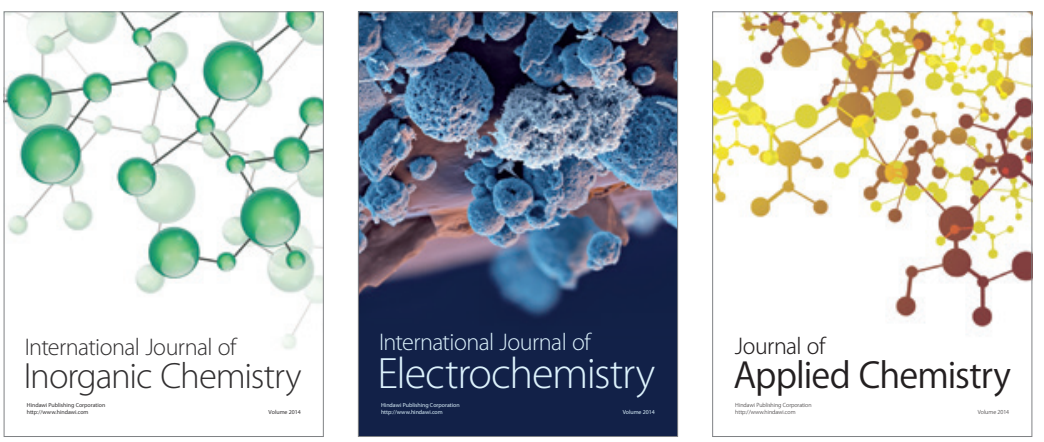

Journal of

Applied Chemistry
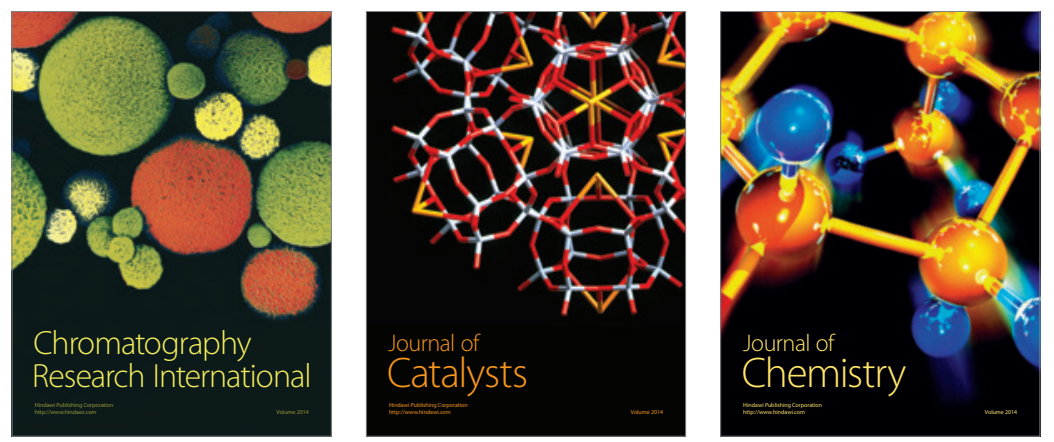
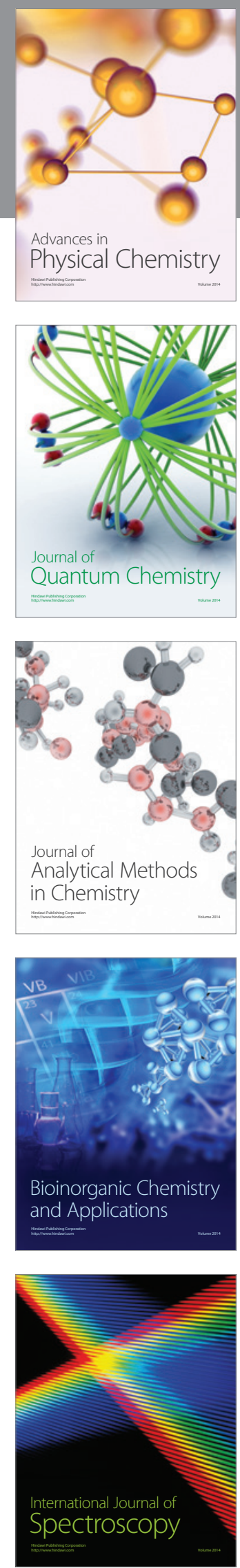